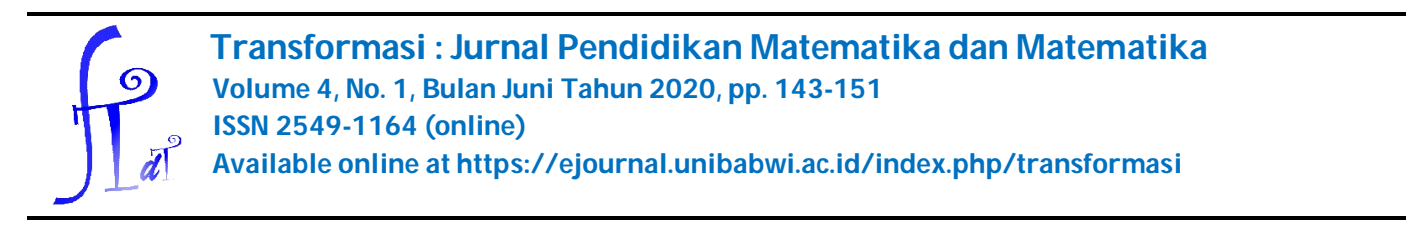

\title{
KEMAMPUAN PEMECAHAN MASALAH PADA MATERI BANGUN DATAR DITINJAU DARI PERBEDAAN GENDER
}

\author{
Rika Wahyuningsih ${ }^{1}$, Heni Pujiastuti ${ }^{2}$ \\ 1,2 FKIP, Universitas Sultan Ageng Tirtayasa \\ email korespondensi : rkwnsh@gmail.com
}

Diterima : 13-04-2020, Revisi: 26-05-2020, Diterbitkan : 25-06-2020

\begin{abstract}
ABSTRAK
Penelitian ini bertujuan untuk mendeskripsikan kemampuan pemecahan masalah pada materi bangun datar yang ditinjau berdasarkan perbedaan gender. Penelitian ini menggunakan metode deskriptif kualitatif. Waktu penelitian dilaksanakan pada semester genap tahun ajaran 2019/2020. Subjek penelitian ini berjumlah 6 siswa, 3 siswa laki-laki dan 3 siswa perempuan. Instrumen yang digunakan dalam penelitian ini yaitu tes kemampuan pemecahan masalah berbentuk uraian sebanyak tiga soal dengan materi bangun datar, dan wawancara. Data yang diperoleh menunjukkan kemampuan pemecahan masalah siswa perempuan lebih unggul dibandingkan siswa laki-laki. Hal ini dapat dilihat dari hasil perolehan skor rata-rata yang diperoleh per soal. Siswa perempuan biasanya cenderung lebih cermat dan teliti dalam menghadapi suatu permasalahan soal pemecahan masalah dibandingkan siswa laki-laki yang terburu-buru-buru dan kurang teliti.
\end{abstract}

Kata kunci : Kemampuan Pemecahan Masalah, Bangun Datar, Gender

\section{ABSTRACT}

This study aims to describe the ability of problem solving in two-dimentional figure material that is reviewed based on gender differences. This research uses descriptive qualitative method. The time of the study was carried out in the even semester of the 2019/2020 school year. The subjects of this study were 6 students, 3 male students and 3 female students. The instrument used in this study was the test of problem-solving ability in the form of a description of as many as three questions with material to two-dimentional figureand interview. The data obtained shows that the problem solving ability of female students is superior to that of male students. This can be seen from the results of the acquisition of the average score obtained per item. Female students usually tend to be more careful and thorough in dealing with a problem solving problem than male students who are in a hurry and are less through.

Keywords : Problem Solving Ability, Two-Dimentional Figure, Gender 


\section{Pendahuluan}

Secara empiris, matematika terbentuk berdasarkan pengalaman manusia yang diproses dalam dunia rasio, dianalisis dengan penalaran dalam struktur kognitif sehingga menghasilkan konsep-konsep matematika yang mudah dipahami (Rahmah, 2018). Matematika merupakan salah satu bidang ilmu yang sangat bermanfaat untuk kehidupan sehari-hari. Dalam menjalani kehidupan ini tidak terlepas dari peran matematika didalamnya seperti menghitung laba rugi, menetapkan harga suatu barang, pemberian uang saku kepada anak, dan lainnya. Matematika sekolah memiliki beragam tujuan seperti mengembangkan kemampuan siswa dalam berhitung dan mengaplikasikan rumus matematika dalam kehidupan sehari-hari. Oleh sebab itu, matematika penting untuk dipelajari oleh semua peserta didik mulai dari jenjang taman kanak-kanak hingga sekolah menengah dan bahkan di Perguruan Tinggi.

National Council of Teacher of Mathematics (NCTM, 2000) menetapkan lima standar kemampuan matematis yaitu kemampuan pemecahan masalah (problem solving), kemampuan pemahaman dan pembuktian (reasoning and proof), kemampuan komunikasi (communication), kemampuan koneksi (connections). dan kemampuan representasi (representation). Setiap siswa diharuskan untuk memiliki kemampuan pemecahan masalah karena merupakan salah satu inti dalam proses pembelajaran (Maharani, 2018). Tujuan dari pembelajaran matematika yaitu mampu mengembangkan kemampuan pemecahan masalah yang terdiri dari memahami masalah, menyusun rencana penyelesaian, menentukan rencana penyelesaian, dan memeriksa kembali. Siswa yang dapat mengimplementasikan tujuan tersebut kedalam pembelajaran matematika membuktikan siswa memiliki kemampuan pemecahan masalah yang baik.

Problem Solving must be the focus of school mathematics artinya kemampuan pemecahan masalah perlu dijadikan fokus dalam pembelajaran matematika (Novianti, dkk., 2017). Ini disebabkan karena kemampuan pemecahan masalah menekankan aktivitas siswa dalam menyajikan proses dan prosedur untuk menyelesaikan suatu permasalahan. Siswa diharapkan mampu untuk menjelaskan permasalahan dengan cara yang berbeda dari pembelajaran yang disampaikan oleh guru. Pembelajaran matematika akan lebih bermakna jika siswa dapat mengatasi kesulitan dalam memecahkan soal matematika. Pemecahan masalah merupakan suatu proses individu dalam mengatasi kesulitan ketika suatu jawaban atau metode jawaban masih dipertanyakan kebenarannya. Pemecahan masalah menjadi salah 
satu komponen penting dalam pembelajaran matematika.

Di Indonesia masih diperlukan perhatian khusus dalam kemampuan pemecahan masalah karena rendahnya tingkat kemampuan pemecahan masalah siswa. Ini dibuktikan berdasarkan hasil analisis yang dilakukan oleh Trends in International Mathematics and Science Study (TIMSS) yaitu siswa Indonesia berada pada posisi 41 dari 45 negara. Ini menunjukkan siswa Indonesia berada pada peringkat rendah dalam kemampuan: (1) memahami informasi yang kompleks; (2) teori, analisis dan pemecahan masalah; (3) pemakaian alat, prosedur dan pemecahan masalah; dan (4) melakukan investigasi (Haloho, 2016). Hasil ini dapat menjadi acuan dalam memperbaiki proses pembelajaran matematika khususnya kemampuan pemecahan masalah.

Kemampuan pemecahan masalah akan melatih siswa agar terbiasa menghadapi berbagai permasalahan dalam matematika maupun permasalahan dalam kehidupan sehari-hari. Siswa dikatakan telah memiliki kemampuan pemecahan masalah jika siswa mampu memahami soal, mampu merencanakan pemecahan masalah, mampu melakukan perhitungan dan tidak lupa untuk memeriksa kembali perhitungan yang telah dilakukan (Nurdalillah \& Syahputra, 2013).

Kemampuan pemecahan masalah pada setiap siswa memiliki perbedaan. Salah satu faktor yang mempengaruhi perbedaan tersebut yaitu gender. Perbedaan gender adalah perbedaan peran, fungsi, dan tanggung jawab antara laki-laki dan perempuan yang merupakan hasil konstruksi sosial dan dapat berubah sesuai dengan perkembangan zaman (Nurmasari, dkk., 2014). Perbedaan gender akan memberikan pengaruh terhadap kemampuan dalam matematika dan cara memperoleh pengetahuan matematika (Susento, 2006). Hal ini sejalan dengan pendapat Khaerunnisa (2016) yang menyatakan bahwa terdapat perbedaan kecerdasan seseorang dalam menghadapi masalah antara laki-laki dan perempuan. Tujuan dari penelitian ini yaitu untuk mengetahui kemampuan pemecahan masalah siswa ditinjau dari perbedaan gender.

\section{Metode Penelitian}

Metode yang digunakan dalam penelitian ini adalah metode deskriptif kualitatif yang bertujuan untuk menganalisis kemampuan pemecahan masalah siswa sekolah menengah pertama. Penelitian kualitatif adalah pengumpulan data atau prosedur penelitian yang menghasilkan data deskriptif berupa kata-kata tertulis dari 
suatu individu yang dapat diamati dan diteliti menggunakan metode ilmiah (Moleong, 2010).

Waktu penelitian pada semester genap tahun ajaran 2019/2020. Subjek penelitian adalah siswa dan siswi kelas VII di salah satu SMP Negeri di Kramatwatu yang terdiri dari 6 siswa, 3 siswa laki-laki dan 3 siswa perempuan, yang dipilih secara acak pada salah satu kelas. Teknik pengambilan data pada penelitian ini yaitu tes kemampuan pemecahan masalah dan wawancara. Instrumen yang digunakan dalam penelitian ini yaitu tes kemampuan pemecahan masalah berbentuk uraian sebanyak tiga soal dengan materi bangun datar dan pedoman wawancara.

Teknik analisis data dilakukan dengan mendeskripsikan data dari subjek penelitian yang telah dipilih berdasarkan indikator pemecahan masalah Polya. Langkah pemecahan masalah yang dikemukakan oleh Polya yaitu: (1) memahami soal ini berarti siswa mampu memahami masalah yang diberikan pada soal dan mampu mengetahui apa yang ditanyakan pada soal; (2) menyusun rencana penyelesaian ini berarti siswa mampu membuat model matematika untuk selanjutnya menuliskan langkah-langkah untuk menyelesaikan soal; (3) melaksanakan rencana untuk menyelesaikan soal ini berarti siswa dapat menerapkan model matematika atau rencana penyelesaian yang telah dibuat sebelumnya; dan (4) memeriksa kembali ini berarti siswa melakukan pengecekan terhadap jawaban soal yang telah dikerjakan (Polya, 1973).

\section{Hasil dan Pembahasan}

Berikut hasil data kemampuan pemecahan masalah siswa berdasarkan perbedaan gender

Tabel 1. Temuan Data Hasil Penelitian

\begin{tabular}{cccccc}
\hline \multirow{2}{*}{ Kode Siswa } & \multicolumn{3}{c}{ Skor Per Soal } & \multirow{2}{*}{ Total Skor } & Skor Maksimum \\
\cline { 2 - 5 } & $\mathbf{1}$ & $\mathbf{2}$ & $\mathbf{3}$ & & 30 \\
\hline L1 & 6 & 4 & 8 & 18 & 30 \\
\hline L2 & 8 & 7 & 7 & 25 & 30 \\
\hline L3 & 4 & 3 & 0 & 7 & 30 \\
\hline P1 & 6 & 4 & 7 & 17 & 30 \\
\hline P2 & 7 & 7 & 8 & 22 & 30 \\
\hline P3 & 7 & 8 & 3 & 18 &
\end{tabular}

Disajikan tabel langkah penyelesaian soal pemecahan masalah sesuai dengan langkah Polya dari subjek L1 (salah satu siswa laki-laki). 
Tabel 2. Langkah penyelesaian subjek L1

\begin{tabular}{|c|c|c|c|}
\hline \multirow{2}{*}{ Langkah Polya } & \multicolumn{3}{|c|}{ No Soal } \\
\hline & 1 & 2 & 3 \\
\hline Memahami soal & $\begin{array}{l}\text { Memahami sisi pada } \\
\text { persegi }\end{array}$ & $\begin{array}{l}\text { Menyebutkan dan } \\
\text { memahami panjang } \\
\text { dan lebar pada per- } \\
\text { segi panjang }\end{array}$ & $\begin{array}{l}\text { Mengetahui kompo- } \\
\text { nen pada trapesium } \\
\text { sama kaki dengan } \\
\text { benar }\end{array}$ \\
\hline $\begin{array}{l}\text { Menyusun ren- } \\
\text { cana }\end{array}$ & $\begin{array}{l}\text { Menyebutkan keliling } \\
\text { persegi dengan benar }\end{array}$ & $\begin{array}{l}\text { Menyebutkan rumus } \\
\text { persegi panjang den- } \\
\text { gan benar }\end{array}$ & $\begin{array}{l}\text { Memahami cara un- } \\
\text { tuk mengetahui tinggi } \\
\text { trapesium sama kaki } \\
\text { meskipun hanya } \\
\text { mendapat petunjuk } \\
\text { dari keliling trape- } \\
\text { sium }\end{array}$ \\
\hline $\begin{array}{l}\text { Melaksanakan } \\
\text { rencana }\end{array}$ & $\begin{array}{l}\text { Pada bagian menghi- } \\
\text { tung keliling persegi } \\
\text { sudah benar namun } \\
\text { tidak melaksanakan } \\
\text { proses pembagian } \\
\text { jarak }\end{array}$ & Tidak melakukan & $\begin{array}{l}\text { Menghitung luas tra- } \\
\text { pesium sama kaki } \\
\text { setelah mengetahui } \\
\text { tingginya }\end{array}$ \\
\hline $\begin{array}{l}\text { Memeriksa } \\
\text { kembali }\end{array}$ & Tidak melakukan & Tidak melakukan & Tidak melakukan \\
\hline
\end{tabular}

Subjek L1 masih mengalami kesulitan dalam menyelesaikan soal nomor satu pada langkah melaksanakan rencana hal ini terlihat dari hasil tes uraian dan tes wawancara. Saat tes wawancara subjek L1 tidak bisa menjawab bagaimana proses pembagian jarak yang akan ditanami tumbuhan pada sebuah bidang persegi tetapi dapat menentukan keliling dari persegi Pada soal nomor dua langkah melaksanakan rencana, subjek L1 tidak bisa mengerjakan soal sama sekali meskipun dapat menyebutkan hal-hal yang diketahui dan ditanyakan serta dapat menyebutkan rumus persegi panjang dengan benar. Pada soal nomor tiga, subjek L1 mampu memahami soal karena menyebutkan harga tiap $m^{2}$ sawah berbentuk trapesium sama kaki, menyebutkan keliling trapesium sama kaki dengan benar sesuai soal yang tertera, serta mampu menyebutkan hal yang ditanyakan pada soal dengan lancar. Pada bagian menyusun rencana subjek L1 dapat mencari tinggi trapesium 
sama kaki menggunakan keliling yang sudah disajikan pada soal. Subjek L1 tidak dapat mengetahui kebenaran dari jawaban yang telah dikerjakan sehingga dalam hal ini subjek L1 tidak melaksanakan langkah memeriksa kembali dengan benar pada setiap soal yang diberikan.

Selanjutnya disajikan tabel langkah penyelesaian soal pemecahan masalah sesuai dengan langkah Polya dari subjek P3 (salah satu siswa perempuan).

Tabel 3. Langkah penyelesaian subjek P3

\begin{tabular}{|c|c|c|c|}
\hline \multirow{2}{*}{ Langkah Polya } & \multicolumn{3}{|c|}{ No Soal } \\
\hline & 1 & 2 & 3 \\
\hline Memahami soal & $\begin{array}{l}\text { Memahami sisi pada } \\
\text { persegi }\end{array}$ & $\begin{array}{l}\text { Menyebutkan dan } \\
\text { memahami panjang } \\
\text { dan lebar pada per- } \\
\text { segi panjang }\end{array}$ & $\begin{array}{l}\text { Mengetahui kompo- } \\
\text { nen apa saja yang } \\
\text { terdapat pada trape- } \\
\text { sium sama kaki }\end{array}$ \\
\hline $\begin{array}{l}\text { Menyusun ren- } \\
\text { cana }\end{array}$ & $\begin{array}{l}\text { Menyebutkan keliling } \\
\text { persegi dengan benar }\end{array}$ & $\begin{array}{l}\text { Menyebutkan rumus } \\
\text { persegi panjang den- } \\
\text { gan benar }\end{array}$ & $\begin{array}{l}\text { Mengetahui keliling } \\
\text { trapesium sama kaki } \\
\text { tetapi tidak dapat } \\
\text { mencari tingginya }\end{array}$ \\
\hline $\begin{array}{l}\text { Melaksanakan } \\
\text { rencana }\end{array}$ & $\begin{array}{l}\text { Menghitung keliling } \\
\text { persegi dan menghi- } \\
\text { tung pembagian jarak } \\
\text { tiap-tiap sisi dalam } \\
\text { persegi dengan benar }\end{array}$ & $\begin{array}{l}\text { Mengaplikasikan ru- } \\
\text { mus persegi panjang } \\
\text { ke dalam soal dengan } \\
\text { baik }\end{array}$ & Tidak melakukan \\
\hline $\begin{array}{l}\text { Memeriksa } \\
\text { kembali }\end{array}$ & Tidak melakukan & Tidak melakukan & Tidak melakukan \\
\hline
\end{tabular}

Subjek P3 mampu memahami soal dengan baik, ini terlihat dari tes tertulis karena dapat menuliskan apa saja yang diketahui dan apa yang ditanyakan soal. Pada langkah menyusun rencana, subjek P3 dapat membuat model matematika dari dua buah atap berbentuk persegi panjang yang akan dicari tiap $m^{2}$ untuk menentukan banyaknya genteng yang dibutuhkan. Subjek P3 juga dapat melaksanakan rencana dengan baik sesuai dengan model matematika yang telah dibuat sebelumnya. Tetapi subjek P3 tidak mengecek jawaban setiap kali selesai mengerjakan tiap-tiap soal sehingga dalam hal ini subjek P3 tidak melaksanakan langkah memeriksa kembali dengan benar pada setiap soal yang diberikan. Pada soal nomor tiga, subjek P3 hanya bisa menuliskan apa saja yang diketahui dalam soal, ditanyakan dalam soal, dan menuliskan rumus luas trapesium sama kaki. Subjek P3 tidak dapat mencari tinggi trapesium sama kaki sehingga tidak mampu melaksa- 
nakan langkah selanjutnya.

Pemecahan masalah matematika membutuhkan pengetahuan awal atau pengetahuan dasar untuk dapat memahami soal (Nugrahaningsih, 2012). Ini berarti siswa laki-laki maupun siswa perempuan sudah memiliki pengetahuan awal karena dapat memahami soal dengan baik. Pengetahuan awal atau pengetahuan dasar ini biasanya didapatkan siswa melalui pembelajaran yang dilakukan sebelumnya bersama dengan guru atau orang tua, pembelajaran di rumah yang dilakukan secara individu, dan hasil berdiskusi dengan teman sebaya. Pada langkah melaksanakan rencana, subjek L1 tidak memperhatikan soal dengan teliti sehingga mengalami kekeliruan. Hal ini sejalan dengan pendapat Putri \& Susilowati (2016) yang menyatakan jika siswa laki-laki cenderung kurang teliti, terburu-buru dan cenderung menyelesaikan sesuatu dengan cara yang singkat sedangkan siswa perempuan biasanya lebih unggul dalam ketepatan, ketelitian, kecermatan, dan keseksamaan berpikir/ bernalar. Siswa perempuan lebih mampu mengatasi pemecahan masalah yang bersifat holistik sedangkan siswa laki-laki lebih kuat dalam menganalisis permasalahan yang bersifat spesifik (Colomeischia, 2014). Berdasarkan hasil pada Tabel 2 dan Tabel 3, siswa laki-laki maupun siswa perempuan tidak melakukan langkah Polya memeriksa kembali.

Selanjutnya pada Tabel 4 disajikan skor rata-rata berdasarkan hasil data pada Tabel 1.

Tabel 4. Skor Rata-rata yang Diperoleh Per Soal

\begin{tabular}{cccc}
\hline \multirow{2}{*}{$\begin{array}{c}\text { Nomor } \\
\text { Soal }\end{array}$} & \multicolumn{2}{c}{ Skor Rata-rata } & Skor Ideal \\
\cline { 2 - 3 } & Laki-laki & Perempuan & \\
\hline 1 & 6.00 & 6.67 & 10.00 \\
\hline 2 & 4.67 & 6.34 & 10.00 \\
\hline 3 & 5.00 & 7.67 & 10.00 \\
\hline
\end{tabular}

Dari data yang diperoleh skor rata-rata siswa perempuan pada setiap soal lebih tinggi dibandingkan skor rata-rata laki-laki. Pada soal nomor satu skor rata-rata perempuan lebih tinggi 0.67, pada soal nomor dua skor rata-rata perempuan lebih tinggi 2.33, dan pada soal nomor tiga, skor rata-rata perempuan lebih tinggi 2.67. Sehingga dapat dikatakan bahwa kemampuan pemecahan masalah pada penelitian ini siswa perempuan sedikit lebih unggul dibandingkan siswa laki-laki.

\section{Kesimpulan}

Siswa laki-laki dan siswa perempuan memiliki kemampuan yang sama pada lang- 
kah memahami soal. Pada langkah Polya yang terakhir yaitu memeriksa kembali, siswa laki-laki maupun siswa perempuan tidak melakukannya sama sekali pada ketiga soal yang diberikan. Berdasarkan hasil dan pembahasan dari hasil penelitian dapat ditarik kesimpulan kemampuan pemecahan masalah siswa perempuan sedikit lebih unggul dibandingkan siswa laki-laki.

\section{Ucapan Terimakasih}

Penulis ingin mengucapkan terimakasih yang sebesar-besarnya kepada pihak-pihak yang telah membantu penulis dalam pembuatan artikel ini. Ucapan terimakasih yang tulus penulis sampaikan kepada: Kepala Sekolah dan guru disalah satu SMP Negeri Kramatwatu serta keluarga dan teman sejawat yang telah memberikan semangat dan motivasi dalam menyelesaikan artikel ini.

\section{Daftar Pustaka}

Colomeischia. (2014). The Student Emotional Life and Their Attitude Toward Mathematics Learning. Procediao Social and Behavioral Science , 180-.

Haloho, S. (2016). Analisis Kemampuan Pemecahan Masalah Ditinjau dari Gaya Kognitif Siswa pada Model Pembelajaran Missouri Mathematics Project.

Khaerunnisa, E. (2016). Studi Deskriptif Adversity Quotient Matematis. Jurnal Penelitian dan Pembelajaran Matematika, Vol. 9, No. 1 , 83-92.

Maharani, S., \& Bernard, M. (2018). Analisis Hubungan Resiliensi Matematik Terhadap Kemampuan Pemecahan Masalah Siswa pada Materi Lingkaran. JPMI (Jurnal Pembelajaran Matematika Inovatif), Vol. 1, No. 5 , 819-826.

Moleong, L. (2010). Metodologi Penelitian Kualitatif. Bandung: Remaja Rosdakarya. NCTM. (2000). Principle and Standard for School Mathematics. Roston.

Novianti, D., Khorotunnisa, A., \& Indirani, A. (2017). Profil Pemecahan Masalah Matematika dalam Menyelesaikan Permasalahan Pemrograman Linear Ditinjau dari Kemampuan Komunikasi Matematis. Jurnal Ilmiah Pendidikan Matematika, Vol. 6, No. 1 , 53-59.

Nugrahaningsih, T. K. (2012). Metakognisi Siswa Sma Kelas Akselerasi Dalam Menyelesaikan Masalah Matematika. Magistra, Vol. 24, No. 82, 37-50.

Nurdalillah, Edi Syahputra, \& D. A. (2013). Perbedaan Kemampuan Penalaran Matematika dan Pemecahan Masalah Pada Pembelajaran Berbasis Masalah dan 
Pembelajaran Konvensional di SMA Negeri 1 Kualuh Selatan Selatan. Jurnal Pendidikan Matematika PARADIKMA, Vol. 16, No. 2, 109-119.

Nurmasari, N., Kusmayadi, T. A., \& R. (2014). Analisis Berpikir Kreatif Siswa dalam Menyelesaikan Masalah Matematika pada Materi Peluang ditinjau dari Gender Siswa Kelas XI IPA SMA Negeri 1 Kota Banjarbaru Kalimantan Selatan. Jurnal Elektronik Pembelajaran Matematika, Vol. 2, No. 4, 351-358.

Polya. (1973). How to Solve it (New of Mathematical Method). New Jersey: Prince University Press.

Putri, J., \& Susilowati, A. (2016). Profil Penalaran Siswa SMP dalam Pemecahan, Vol. 1, No. 2, 132-148.

Rahmah, N. (2018). Hakikat Pendidikan Matematika. Al-Khwarizmi: Jurnal Pendidikan Matematika Dan Ilmu Pengetahuan Alam, Vol. 1, No. 2, 1-10. https:// doi.org/ 10.24256/jpmipa.v1i2.88

Susento. (2006). Mekanisme Interaksi Antara Pengalaman Kultural-Matematis, Proses Kognitif, dan Topangan dalam Reivensi Terbimbing. Surabaya: Unesa. 